\title{
REDUCING POVERTY BY THE MANAGEMENT OF SOCIAL INNOVATION
}

\author{
Flávio de São Pedro Filho ${ }^{1}$, Ademar Roque Lorenzon², Norma Maria Coelho Vieira ${ }^{3}$, \\ Marcelo José Peres Gomes da Silva ${ }^{4}$, Valeria Arenhardt ${ }^{5}$ \\ ${ }^{1}$ Post-Doctoral researcher in Management and Economics at the University of Beira Interior, \\ Portugal. Doctor of Business Management from the Universidad Autónoma de Asunción, \\ Paraguay. Doctor of Administration from the University of São Paulo, Brazil. Coordinator of the \\ Research Group on Management of Innovation and Technology (GEITEC), Brazil. E-mail: \\ flavio1954@gmail.com
}

${ }^{2}$ Lawyer and entrepreneur in the city of Pimenta Bueno, State of Rondônia, Brazil. Contributor of the Research Group on Management of Innovation and Technology (GEITEC), Brazil. E-mail: roquelorenzon@hotmail.com

${ }^{3}$ Master's Degree Student in Environmental Sciences from the University of Taubaté (UNITAU). Contributor of the Research Group on Management of Innovation and Technology (GEITEC), Brazil. E-mail: coelho.norma@gmail.com

${ }^{4}$ Specialist in Computer Networks and Data Communications at the State University of Londrina (UEL). Contributor of the Research Group on Management of Innovation and Technology

(GEITEC), Brazil. E-mail: engcompmarcelo@hotmail.com

${ }^{5}$ Doctoral researcher in Environmental Technology at the University of Ribeirão Preto. Contributor of the Research Group on Management of Innovation and Technology Management (GEITEC),

Brazil. E-mail: valeria.arenhardt@ifro.edu.br

\begin{abstract}
Sustainable tourism systems have several variables with significant implications, poverty being one of the more obscure of them, which in conjunction with hunger, inevitably leads in the end to social chaos. The general goal of this project is to study the state of the art in social innovation focusing on the elaboration of valid ideas for it, based on developments for reducing poverty in ecotourist communities. Its specific objectives are (1) to study the management of the ecotourism business as a successful tool in social innovation (2) to indicate the social technologies for forming eco villages and social innovation in ecotourist communities, and (3) to interpret the social technologies associated with domestic orchards and gardens as a new arena of socio- spatial performance. It is based on the Theory of Planned Behavior, derived from the Theory of Rational Behavior consistent with information handling that encourages collective action, models inherent in Azjen and Fishbein's list of multiple attributes. This task called for qualitative research of a constructivist nature, as a simulated study of case methods used as preparation tools. The studied population was located on the north coast of Bahia State (Brazil), in a population of mainly unassisted locals
\end{abstract}


and visitors, whose main object is to enjoy the scenery. The results of this study of the present state of affairs point to the paradox which characterizes this pleasurable environment for ecotourism, with its fertile soil, interesting culture and typically hospitable hosts. The design proposed below gains support from social technologies associated with permaculture, rural methods and other behaviours geared to organizing productive systems that are modelled on ecotourism-centered eco-villages. The conclusion of this task was that the residents' practice in social innovation should effectively reveals a gap between what exists and what should exist. The solution lies in training individuals and collectives to exploit the regional potential for changing their conditions, for instance by developing the technology to maximize their control of the environment, thus reducing poverty and improving the quality of life. This would merit a seal of conservation for production directed to self-consumption and profit from any surplus. This is a proposal to reduce poverty through a socioeconomic transition to sustainability by ecotourism-centred communities using social technologies.

Keywords: Administration. Ecotourism. Knowledge. Management. Social innovation.

\section{INTRODUCTION}

This work focuses on ecotourism management in an informal economy, using economically leveraged instruments and applying social innovation and social technologies. In detail, it considers the organization of domestic orchards and gardens in eco-villages seeking to raise the income of host communities in tourist areas. It includes such topics as participative ecotourism, culture, training, domestic family production and so on. Its purpose is to implement wider collective self-management for communities through association and cooperation, an idea discovered in the spontaneous vision of its members. It tries to encourage the creation of ideas for reducing poverty in rural communities through valid instruments until they have reached the point of sustainability. This paper is justified if it can contribute proposals based on citizenship for renewing living conditions and can impact of human reductionism in the face of chaotic irrationality. The general goal in this project is study the current state of elaboration attained by ideas for social innovation in ecotourist communities with the aim of reducing rural poverty. The specific objectives are (1) to study the business management of ecotourism as a tool for social innovation, (2) to indicate some social technologies for social innovation in eco villages and ecotourist communities, and (3) to interpret the social technologies at the level of domestic orchards and gardens as a new socio spatial phenomenon

\section{LITERATURE REVIEW}

Studies from Santos (2011) suggest that the Behavioral Determiners treated by Bogozzi (1981), cited by Beedell \& Rehman (2000), affirm that past investigations of the farmers' motivations are subjective. It is doubtful if this study format can be applied to the social actors in ecotourist sites, since it emphasizes the use of the Planned Behavioral Theory, derived from the Rational Behavioral Theory of Ajzen and Fishbein (2000). This consists of the treatment of information about the modelling of multiple attributes. Autochthonous subjectivism represents the state of art when authors prescribe valid social models generated by themselves as reality.

Looking at the literature in greater depth reveals that multiple attribute modelling derives from the collective creed of behavioral nature, both normative and control, which results in attitudes, social rules and control of perceived behavior dominating first intention and next behavior, similar to that of Jackson (2005). This variant fits the directing of simulations to the expectation of generating something that will persuade the social actors in a specific area to change their behavior. It has been observed that agents who expect public money to support their already precarious subsistence have a tendency to be lazy when they are asked to produce quality goods and benefit from the surplus using what the environment provides.

Academics studying the Amazon region are still investigating the similarities between practices developed by local indigenous people and the Caribe woodsmen; however it is possible to check the practiced procedures of the tribesmen and discover whether the creativity is endogenous or whether creative attrition has been manipulation to use the "coivara," a typical tribal technique amongst the Tupi peoples, to form geoagricultural spaces enriched soil and other native social technologies. 


\subsection{Concepts Regarding Innovation and Technology}

Currently, academia gives too little attention to technological innovations originating from folk knowledge. In the applied research field, the MIT Center for Civic Media in the Massachusetts Institute of Technology continues the appropriated technology approach which links up with this work, a decisive inclusion of folk knowledge as regards technology. What happens is that the individual situated in a given indigenous social infrastructure is always, by simple prejudice, viewed as such. Lack of investment in education in developing countries and inadequate training of the workers result in their being further distanced from the formal economy. What predominates in the formal economy is that its procedures are mainly oriented to methods and productive processes directed by engineering in academic terms. It gives an excuse to subjugate some individuals as mere service providers, born to satisfy the expectations of large scale consumption while destroying the environment with its waste products and causing great ecological harm. This unstructured relationship gives rise to tensions between the production of goods and services and men's living conditions. As a result, the categorized approach occurs of the break between inclusion and exclusion. The inconsistency of the dominator's proposal is clear: their interests are geared to political and economic advantages which will bring them immediate benefits. But they do so at the expense of the indigenous peoples, their culture, tradition and time-tested knowledge.

Leonard (2003), from the Harvard Business School conceptualizes creativity as a development process bringing new ideas for the expression of possibility and utility. The author describes four important characteristics of creative action: divergent thought, the transmission of ideas, convergent thought and the option of useful ideas. He also suggests five steps to take: preparation, taking the opportunity to innovate, letting options diverge, incubating creative ideas and convergence to select new options. Studies such as the present one owe much to this author's views. They stimulate the design of new operational tools of development, social technologies amongst them.

\subsection{Concept of Social Technologies}

Social technologies involve straight politics; they are based on folk knowledge turned diverted to the improvement of local practices developed by the local people. They are creative techniques and their innovative adaptors actively consider the environment, the indigenous culture and affirmative action, in response to the originators' immediate needs, included in the process of transforming what is available all around. It is the route from which endogenous communitarian benefits proceed. The Brazilian Ministry of Science and Technology includes a secretary who administers issues related to social technologies. The duties are to transform concepts generated by community interaction as a simple, straightforward low cost solution. It uses local input and labor and its techniques are born from folk knowledge, but the effects of its solutions on the environment and society are ill-considered for the emancipation of all involved.

\subsection{Concept of Social Innovation}

In this study, the idea focuses on the processes and the foreseeable results in an intervention for social innovation by means of increasing the capacity of the residents involved. The study by Benevides et al (2017), based on Emmendoerfer et al (2011) and Correia et al (2015), is centered on social innovation as an economic restructuring strategy to meet demands and solve social problems at the institutional, organizational and individual level. These authors believe that individuals and organizations can bring about social innovation when excluded individuals become responsible for the decision-making in the design and creation of goods and services, and can develop the autonomy to form new relationships in the home and at work. An innovation of this kind involves social intervention as a way of developing and adopting technologies or arrangements by which social relations can be transformed, promoting inclusion by creating income and improvements in the general standard of living. The organization becomes an agent for social innovation by forming new divisions and ways of coordinating work, presenting structural configurations in networks or projects.

Benevides et al (2017) and Emmendoerfer et al (2011) affirm that social innovation in tourism, including ecotourism, is the substitution of macro national policies for regional policies so as to minimize the socioeconomic impact of generating employment, promoting the local culture and income and preserving the natural resources. These authors understand that, as Lima (2011) maintains, social innovation is the effective perception of a gap between what exists and what should exist, together with a search for solutions by training and mobilizing individuals to exploitation the potential of their regional and thus change their situation. 


\subsection{Concepts of Ecotourism and the Environment}

Lindberg (2001) compares the expansion of ecotourism through travel and conservation to that of a tsunami. Ecotourism activities can be traced back to the caravans arriving in Yellowstone Park, Wyoming, in the USA and in Yosemite National Park in the Sierra Nevada Mountains of California. In Brazil, this activity is preferred by elite consumers who love the natural environment, for the attractiveness of magnificent views can motivate wealthy spend to spend lavishly. But when they arrive the micro-businesses involved in catering cannot keep up with their increasing numbers of visitors. To survive, this multidisciplinary phenomenon needs a coherent interpretation, re-designed local production and some adjustment of its main rural infrastructure. Thus, the search for alternative energy, efficient rain recycling techniques, refined methods of domestic and commercial management waste disposal and ceramics-based building techniques continues.

In Morgani's (1996) view, systems theories use subsystem configurations to describe connection systems, as discussed below. Egri \& Pinfield (1998) affirm that organizational activities depend on social, economic, cultural, political and technique-based systems. It is these criteria that determine what supply knowledge and technology will be processed, objectivizing valid forms of provisioning for society.

\section{METHODOLOGICAL DESIGN}

This task required as a first step a literature review which helped to orient the study to the remaining steps, unavoidable paradox. A case is a description of an administrative situation, usually involving a problem or decision. It is described from the point of view of those involved with a key problem or decision regard to the case, and traces the steps taken and ananalysis of the process followed. The Case Study method in sociological research is most appropriately applied to situations such as this one, and is thus applied to the present work. However, it thereby exposes the investigator to common critiques in methodology, and offers significant opportunities to administrative science.

A social scope imposes much more rigor on observation, analysis and critics; literature such as a doctoral thesis by Montibeller Neto (2000) was found which could be used as a basis, revealing procedures and lines of reasoning were found to be helpful. They offer a richness of orientation which pointed out the defects of an extraordinary plan of advanced research in data collection, featuring the McGranth Circumplex, which is a functional diagram for a cognitive strategy in developing a research action type of research; however, this did not seem quite appropriate to the present project. Consequently, it was decided that the the best choice was the case study method, taking a qualitative approach and following a line of constructivist phenomenology based on the literature, data collection and observation. The design procedures obeyed the methodology described by other authors. Questionnaires were distributed and interviews were held in order to objectify an essential qualitative investigative line. Interviewees were asked open-ended questions, making information when needed. Visits were made on-site, to learn about its cultural and environmental attributes. Information analysis demanded cross-checks with official bodies of data - while this was in general an ill-structured method, it points to a way of eliciting where hidden facts can be brought to light. A critique based on the theoretical and conceptual content of the literature review was made.

\section{MANAGING SOCIAL INNOVATION SO AS TO REDUCE POVERTY: A CASE IN BRAZIL}

In this section the subsystems which complement the proposed production system are analyzed as a solution to the poverty besetting the residents of the micro region under study. We analyze the issues related to environmental education and ways of preparing visitors and residents to adjust themselves to the social model here proposed. A system of full employment, socioeconomically leveraged, uses what is available in the environment. In this, it is necessary to identify the first tools for collective action in the present context, in the content of a program for a philosophy of eco-villages and permaculture. This construction should be complemented by considered the domestic orchards and gardens as an organized approach to achieving the desired objectives.

\subsection{Ecotourist Business Management as a Tool for Social Innovation}

To approach politics, participative planning and management as appropriate answers to the problems of using natural and human resources in ecotourism, one must (1) reflect on the steps required to earn ISO 14000 certification; (2) work on growth, emphasizing managed ecotourism that can work long term within its load capacity; (3) change to a mindset recognizing that sustainable ecotourism management is more than environmental. It is also economic, social, cultural, political and administrative. To acquire ISO 9000 
certification, one must be mindful of several crucial points: First, one must recognize the importance of satisfying the needs and aspirations of individuals, which implies a preoccupation with equal justice. Second, one must follow constructivism in decisions, with the participation and consultation of all parties involved, so that maximum compromise can be achieved regarding development questions. Third, one must encourage the dissemination of sustainable ecotourism ideas, understanding that the beginning and end of each sustainable development action phase, with clearly identified politics and objectives for each phase, is crucial to the aggregation process. Fourth, one must comprehend the intricate details of the given market economies, and be familiar with the cultures, private business management procedures, volunteer organizations, the values and the attitudes of the locals, so that good intentions can be turned into practical measures. Fifth, one must pass on advantages in order to establish vital compromises, surmounting the frequent conflicts between interests when it comes to resource distribution.

\subsubsection{Participative Ecotourism on the Studied Region}

The developmental strategy in question did not distinguish ecotourism very clearly from traditional tourism. Ecotourism is any activity leading to the exploration of environmental attributes, both natural and cultural, made available to visitors for their leisure and entertainment. Official tourism bodies note that ecotourism is amongst the most rapidly expanding sectors of tourism. However, this activity yields a disproportionately small revenue, further exacerbated in some regions by unsustainable development and wealth generation.

Investment in transportation, electricity and environmental recovery has added to the ecotourism business. As a result of this infrastructure, ecotourism has grown at a geometric rate and is now responsible for nearly $70 \%$ of all tourist-based income in Bahia State, as its most attractive option for the leisure and entertainment of Brazilians and foreigners travelling to the state. All the infrastructural investment, however, has not acknowledged the misery of the current struggle.

\subsubsection{Education for Behavioral Change and Integration}

As observed in the present study, local and foreign users of the ecotourism services have not influenced each other in matters of environmental education, which is the concern of the second subsystem of this work. The communitarian integration politics elaborating on the charms of the region merit a review, for example, that of Costa dos Coqueiros, situated on the north coast, Chapada Diamantina in the central west and others in Bahia State. However, conservationists and tourists must not set up nature against the local population. The two must be integrated as parts of the process while transforming the community into beneficiaries of conservation rather than its implacable enemies. The misuse of investors' actions can be rethought. In this way it becomes logical to foster an infrastructurally-minded conservationist pact, reversing damaging actions and offering something in return to favour the hosts in this environment, for the common good. In general, almost nothing, socially speaking, represents a bold investment when it is made at the expense of local misery because it fails to appreciate village structures. The magnificent sophistication of such tourist ventures break these structures down, reducing the villages to nothing; they can generate an astronomical surplus, but offer no exchange, unviable in terms of the very touristic model that welcomes them. The humble spectators and illiterate individuals who form the majority trust business objectives and are only anxious to secure mutual participation in such imposing projects.

\subsection{Social Technologies for Eco-Villages and Social Innovation in Ecotourist Communities}

Eco-villages are settlements situated beyond the urban perimeter. They are composed of simple residential homes, most made of pug or wattle and daub and inhabited by the individuals who are to be prepared for a new socio-economic model live. The sustainable environment factors are alternative energy sources, irrigation and fertilization. The permaculture concept is made up of participative ecotourism, entrepreneurship, handicrafts, cooperative business, hygiene, health care, literacy, training for all, quality of life and developed clusters of tourist activity. It is complemented by local landscaping to bring out the beauty of its attributes, which are admired by visitors and exhibit the quality of life of the inhabitants. Eco villages constitute the third subsystem in this work.

\subsubsection{Integration into the Communities and External Consumers}

The villagers' domestic industry creates other ideas, because it is possible to prepare candies and fruit products harvested from their orchards which are sufficient for their own consumption and for small scale commercialization. Another ideal industry an be formed from the "casas-de-farinha" (flour mills), where manioc and other domestically produced roots are processed. Allied to them are other food products, such 
as the "beiju", various cakes and cookies which can be commercialized in free fairs and established hotels nearby if produced in excess. All this is entirely compatible with the sale of bromeliads and other flowers brought from lakes and streams, all to complete an ideal set of photo images, unforgettable memories which will represent the actual scenery. Various unities, such as a composition of domestic gardens, orchards, industry and culinary delights evoke regional colors as part of an eco-village in accordance to Table 1 in bellow.

Table 1: Main input basic details for an eco-village building.

\begin{tabular}{|l|l|}
\hline \multicolumn{1}{|c|}{ Input Type } & \multicolumn{1}{|c|}{ Applying environmental elements through social technology } \\
\hline 1. Physical Area & $\begin{array}{l}\text { 1.1 Fertile plains, perfect for needed plantations or perfect landscapes for } \\
\text { private properties, the installation of "casas de farinha" and so on. 1.2 For the } \\
\text { appropriation of environmental service arrangements. 1.3 For the } \\
\text { management natural plants and further components in order to embellish the } \\
\text { scene according to popular taste. }\end{array}$ \\
\hline 2. Wood Remains & $\begin{array}{l}\text { 2.1 For fixing and supporting, for building an impeller, grinder and press in } \\
\text { order to produce flour. 2.2 For the construction of doors, windows, and } \\
\text { waterwheels for energy production. 2.3 For building fences and pens. }\end{array}$ \\
\hline 3. Clay & $\begin{array}{l}\text { 3.1 For building walls and partitions on annexed buildings, such as flour mills. } \\
\text { 3.2 For constructing floors in interiors and accesses. 3.3 For making vessels } \\
\text { and ovens where locals burn wood for manioc products. }\end{array}$ \\
\hline 4. Palm Tree Straw & \multicolumn{1}{|c|}{ 4.1 For roofing buildings. 4.2 For interior partitions. 4.3 Generally for the } \\
\hline 5. Bamboo Remains & $\begin{array}{l}5.1 \text { Preparing floral ornamental fasteners. 5.2 Decorating pens and pencils } \\
5.3 \text { Cups and household decorative materials. 5.4 For house building. }\end{array}$ \\
\hline $\begin{array}{l}\text { 6. Textiles and similar } \\
\text { remains }\end{array}$ & $\begin{array}{l}\text { 6.1 Clamps for multicolored decorative panels. 6.2 For interior partitions. 6.3 } \\
\text { For ornamental handmade covers. }\end{array}$ \\
\hline 7. Scrap metal & $\begin{array}{l}\text { 7.1 Blades for handicraft work. 7.2 Rim punchers for unusable bicycles. 7.3 } \\
\text { Platforms for decorative seats. 7.4 Iron sheets for the wood ovens used in the } \\
\text { regional cooking. }\end{array}$ \\
\hline Materials & $\begin{array}{l}\text { 8.1 Logs with old roots for external decorative sets, to fix the soil and serve as } \\
\text { supports for wild orchids and for the ovens 8.2 Discarded palm tree branches } \\
\text { with coconuts for exterior ornaments, serving as support for varied green } \\
\text { branches. 8.3 Tree branches and cipó (a type of liana) collected from the } \\
\text { forest to fill up the wattle and daub walls. }\end{array}$ \\
\hline
\end{tabular}

Source: the authors.

\subsubsection{Social Technologies for Permaculture and Quality of Production to Consumers}

Permaculture was developed by the Australians Bill Mollison and David Holmgren. In this study, permaculture outgrows its philosophical concept and starts to build a set of practices, here named valid social technologies. They synthesize traditional activities, which brings up innovative ideas. They involve the planning, implementation and consistent management of productive systems which are as diverse, stable and resilient as natural ecosystems are. This concept was found very proper for ecotourism areas, because $t$ harmoniously integrates people with their landscape, promoting food, energy and habitation in a sustainable way. A continued rural exodus negatively reverberates on the quality of life of the urban zones that accept individuals in flight. The solution here is a permaculture that generates systemic solutions for the rural individual, creating a feeling of love for his space, because the environment offers him accessibly and simply all that he needs for a life with dignity, in his own place, and nothing driving him to migrate elsewhere. It will be the solution to individuals' obsession to find a place for themselves in harmony with the ecosystem. This $t$ is what Soares (1998) meant when he wrote "Practical solutions are needed for rural people. Solutions 
contribute to each region's cultural, social and environmental status - systemic solutions, within reach and straightforward, that bring security for families and the potential for sustainable human development; the Table 2 shows an example of elements for the public domain.

Table 2: Elements of a social technology for a permaculture

\begin{tabular}{|l|l|}
\hline \multicolumn{1}{|c|}{ Element } & \multicolumn{1}{|c|}{ Functional description } \\
\hline 1.Concept & $\begin{array}{l}\text { The concept is of a system whose goal is to confirm the capacity to } \\
\text { generate self-sufficiency in food superseding the public politics that } \\
\text { fails to remedy famine and shortages. }\end{array}$ \\
\hline 2. Organic food production & $\begin{array}{l}\text { This method of food production uses no pesticides or other products } \\
\text { that might damage human health. }\end{array}$ \\
\hline $\begin{array}{l}\text { 3. House building using } \\
\text { ecological techniques }\end{array}$ & $\begin{array}{l}\text { These are measures oriented to construction methods in harmony } \\
\text { with nature and the environment, which allow people to build their } \\
\text { own houses with materials well-known to do no damage to the } \\
\text { environment. }\end{array}$ \\
\hline $\begin{array}{l}\text { 4. Access to water and } \\
\text { responsible r use of it }\end{array}$ & $\begin{array}{l}\text { Research shows that the water concentration exists in 19 countries, } \\
\text { including Brazil where 13.7\% of all water comes from source } \\
\text { centering in the northern region. From this concentration, 59\% is } \\
\text { reserved for agriculture, 22\% for domestic use and 19\% for industrial } \\
\text { use. Responsible consumption refers to the effective ways of reusing } \\
\text { water at no risk to health. }\end{array}$ \\
\hline $\begin{array}{l}\text { 5. Use of renewable sources } \\
\text { for electric power generation }\end{array}$ & $\begin{array}{l}\text { These sources are natural, namely, the sun, wind, water, biomass, } \\
\text { wave-power, geothermal energy, bio combustible energy, friction and } \\
\text { fusion. }\end{array}$ \\
\hline $\begin{array}{l}\text { 6. Sanitation using natural } \\
\text { technologies }\end{array}$ & $\begin{array}{l}\text { These techniques prevent groundwater contamination and have no } \\
\text { negative influence on the environment. The Cleaner Production } \\
\text { Technique is the most recommended method for safeguarding the } \\
\text { environment. }\end{array}$ \\
\hline 7. Waste recycling and reuse & $\begin{array}{l}\text { By these means, nothing is lost; all is transformed by sorting waste } \\
\text { products and knowing how best to use them as raw material for other } \\
\text { products. }\end{array}$ \\
\hline $\begin{array}{l}\text { Equilibrium is the goal of a society with permaculture. Put simply, it is } \\
\text { capable of being absorbed as a way of life. }\end{array}$ \\
\hline
\end{tabular}

Source: The authors.

\subsection{Interpretation of Ways to Apply These Social Technologies for Domestic Orchards, Gardens and New Socio Spatial Performance}

Research studies have pointed out the importance of domestic production. The present study indicates that the main problem for the population in question is famine, which it is hope to combat by attention to the combined effects of various productive systems on fruit and vegetables. At present, such products come to the market from dubious sources; no certified registers of the produce for sale can be found. There is no doubt that numerous establishments acquire produce that is already infected, because much of it is irrigated with water from sanitary sinks, bringing epidemics to local people. An interview with a sanitary engineer revealed cases of unexplained fatigue, due to worms latent in food. The founders revealed that they do not know anything about such risks, beyond pointing to a lack of satisfactory supervision. Inescapably, however, the actual practices, whether deliberately or not, also harm the visiting ecotourists, giving them dysentery, hepatitis and other grave infections that they do not discover until it is too late. A recent incident has been the spread of meningitis throughout the Hotel Complex; it is not yet certain but the probable source is the food served to guests. 
The threat of famine can be averted by greater production from domestic orchards and gardens. The answer may lie in the domestic permaculture, if the municipalities situated mainly in the tourist spots and nearby produced more food. Such enterprises would stimulate further resources to establish organic orchards and gardens, using natural pesticides and other permaculture techniques.

These products are destined to feed the growers firs; if there is any surplus, it should be sent to a horticultural cooperative center to be installed in each tourist zone. This center would sell quality products, such as pumpkins, lettuces, potatoes, eggplants, carrots, green beans, gherkins, okra, tomatoes and dozens of other vegetables and fruits, such as avocados, pineapples, bananas, cashews, coconuts, grapefruit, lemons, watermelons, melons, mangos, tangerines and dozens of others. They would be bought by neighbouring hotel centers, resorts and hostels and by local residents who regularly shop at free markets in the eco villages, according to the structured ecotourism design of each municipality involved in the scheme.

The considerable return from such an initiative would offer to the local economy a synergic plan, mainly for the organic cultivation of vegetables and fruits with no pesticides. Their production costs, on the actual conditions, are of no consequence, since experiments have shown that composting can be done even in an apartment. Other advantages of such horticulture are that it can be fertilized with human waste, cultivated as a form of permaculture, and raise food quality for the native population, as well as for the visitors. The prices of these products in the regular market would certainly be remarked by big metropolitan consumers, to the clear advantage of the rural producers.

During the Second World War the British immediately transformed their parks and flowers gardens into vegetable plots. This initiative came to strengthen the capacity to grow food during periods of conflict. Today, food shortages demand vigorous initiatives from all who engage in civil businesses, as if they were in a state of war against famine. Some resort to canned food, which impairs their health. However, many ranchers with domestic gardens have a long life span, while at the same time they contribute to solving food shortages, and create harmony between themselves, raw nature and a healthy environment. If the present proposition were implemented, it is hoped that social and political attitudes with important economic consequences could be created. Surplus crops thus produced could be commercialized, completing the production chain. An efficient approach would be to compose an integrated ecotourism design and to stimulate cultivation endogenously in people's back gardens, or in whatever spaces are available. Domestic gardens and orchards stand as the main subsystem for this study and Table 3 shows some of the basic details of this idealistic initiative.

Table 3: Main basic details for building an eco-village food economy

\begin{tabular}{|l|l|}
\hline \multicolumn{1}{|c|}{ Input Type } & \multicolumn{1}{c|}{ Application elements through social technology } \\
\hline 1. Manioc Roots & $\begin{array}{l}\text { 1.1 Cakes of carimã. 1.2 Tapioca Beiju. 1.3 Sequilhos - salty and } \\
\text { sweet. 1.4 Flour. }\end{array}$ \\
\hline 2.Citric fruits, such as oranges & 2.1 Compotes. 2.2 Jelly. 2.3 Juices. \\
\hline 3. Papaya & 3.1 Compotes. 3.2 Jelly. 3.3 Crystallized fruits. \\
\hline 4.Medicinal herbs & 4.1 Curative teas. 4.2 Natural essences. 4.3 Mixtures. \\
\hline 5. Organic vegetables and roots & $\begin{array}{l}\text { 5.1 Domestic consumption. 5.2. Selling in free markets. 5.3. } \\
\text { Selling in the regional resorts. }\end{array}$ \\
\hline
\end{tabular}

Source: The authors.

\section{CONCLUSION}

This study does not end here, because it is part of an integrated ecotourist support system. Another study is need to show new configurations for organizing a productive system based on Ecotourist Business Management; for example, there are local florists, folk handicrafts and local fishing, delicacies from candy makers and cooks, flour mills, and cottage industries such as embroidery and crochet, among others. In the end an approximate design will be produced for the integration of micro and small businesses into tourism activities. However, in this first step, we hope that this work can contribute new ideas to administrators, agronomists, landscape architects, economists, sociologists, social workers, and policy-makers to reflect on, 
IJASOS- International E-Journal of Advances in Social Sciences, Vol. III, Issue 9, December 2017

so that their work improves the living conditions of these humble people. Even more than the present authors, they hope to participate in such schemes and offer their collaboration in the common good, cultivating themselves, their orchards and their gardens. We also hope that we have set in motion a great integration of the ideas from visitors and from those who live in the villages which attract ecotourists.

\section{REFERENCES LIST}

Ajzen, I.; Fishbein, M. (2000). Attitudes and attitude-behavior relations. European Review of Social Psychology.

Beedell, J.; Rehman, T. (2000). Using social-psychology models to understand farmers' conservation behavior. Journal of Rural Studies 16. Pages 117-127.

Benevides, S. L. M. et al (2017). Social innovation by tourism strategy in Western Amazon. Proceeding of the Conference of the Global Innovation of Knowledge Academy Lisbon: Innovation, Knowledge, Judgment and Decision-Making as Virtuous Cycles. Lisbon: GIKA, 2017.

Bogozzi, J. (1981) Attitudes, intentions and behavior: a test of some key hypotheses. Journal of Personality and Social Psychology 41, pages 607-627.

Correia, S. E. N. et al. (2015). Community Based Tourism as Social Innovation: congruence between constructs. Magazine of Tourism and Cultural Heritage - Pasos. Vol. 13, n. 5, pp. 1213-1227.

Egri, C. P.; Pinfield, L. T. (1998). As organizações e a biosfera: ecologia e meio ambiente. In: Clegg, S.R.; Hardy C.; Nord, W.R. Handbook de estudos organizacionais. São Paulo: Atlas.

Emmendoerfer, M. L. et al. (2011). Evidences of Social Innovation in Public Management of tourism in Minas Gerais - Brazil: The model of tourist circuits on analysis. PASOS - Magazine of Tourism and Cultural Heritage. Vol. 9, n. 2. pp. 397-410.

Jackson, T. (2005). Motivating sustainable consumption. Center for Environmental Strategy. University of Surrey (UK). Surrey: Report to the Sustainable Development Research Network.

Leonard, D. (2003). Centelhas encandescentes: estimulando a criatividade em grupos. Porto Alegre: Bookman.

Lima, R. P. de. (2011).Community Based Tourism as Social Innovation. (Doctoral thesis). Postgraduate Program in Production Engineering. Federal University of Rio de Janeiro. Rio de Janeiro: COPPE.

Lindberg, K. (2001). Ecoturismo: um guia para planejamento e gestão. São Paulo, SENAC.

Montibeller Neto, G. (2000). O mito do desenvolvimento sustentável. Tese de Doutorado. Universidade Federal de Santa Catarina. Florianópolis: UFSC.

Moreira, D. A. (1998). Introdução à administração da produção e operações. São Paulo: Pioneira.

Morganl, G. (1996). Imagens da organização. Tradução de Cecília Whitaker Bergamini e Roberto Coda. São Paulo: Atlas.

Santos, M. J. P. et al. (2011). As atitudes dos agricultores face à política agrícola comum e ao projeto de Regadio de Alqueva. Brasília: SOBER.

Soares, A. L. J. (1998). Permacultura e design. Conceitos básicos de permacultura. Projeto Novas Fronteitras da Cooperação para o Desenvolvimento Sustentável. 